\title{
The Effect of Organizational Culture, Reward, Transformational Leadership, and Job Satisfaction on Teacher Performance of Muhammadiyah Elementary School Medan
}

\author{
Asrah Feriany M. Harahap* Zainuddin Abdul Muin Sibuea \\ State University of Medan, Jl. Willem Iskandar Psr. V Medan, Indonesia
}

\begin{abstract}
The problem in this study is to find out the influence of organizational culture, honorarium, transformational leadership, and job satisfaction on the performance of teachers at Muhammadiyah Elementary School Medan. The population of this study consisted of 570 people and sample consisted of 235 people. The results shows that the direct influence of organizational culture on teacher job satisfaction with a path coefficient of 0.255 ; direct effect of honorarium on teacher job satisfaction with a path coefficient of 0.248 ; the direct influence of transformational leadership on teacher job satisfaction with a path coefficient of 0.248 ; direct influence of organizational culture on teacher performance with a path coefficient of 0.222 ; direct effect of rewards on teacher performance with a path coefficient of 0.193 ; the direct effect of transformational leadership on teacher performance with a path coefficient of 0.186 ; and the direct effect of job satisfaction on teacher performance with a path coefficient of 0.252 . Based on these findings, it can be concluded that the better the organizational culture, the better the teacher's job satisfaction and the better the reward, the better job satisfaction of the teacher and the better transformational leadership, the better teacher job satisfaction and the better the organizational culture, the better the teacher's performance and the better the honorarium, the better the teacher's performance and the better the transformational leadership, the better the teacher's performance and the better job satisfaction, the better the teacher's performance.
\end{abstract}

Keywords: Organizational Culture, Reward, Transformational Leadership, Job Satisfaction, Performance

DOI: $10.7176 / \mathrm{JEP} / 10-18-21$

Publication date:June $30^{\text {th }} 2019$

\section{INTRODUCTION}

Teachers in carrying out their duties need to be considered and evaluated their performance because teachers have professional assignments. It means tasks that can only be done with special competencies obtained through educational programs. Teacher performance is the ability shown by the teacher in carrying out the task

The quality of teachers is very necessary element in education because the existence of teachers at various levels, some are considered far from the expected performance. The teacher does not only convey academic theories but also become an example illustrated by the behavior of a teacher in everyday life. Basically, those who aspire to become teachers are based on a noble idealism, to create students as qualified future generations.

It is line with Sahulata (2009) the quality of education is still considered low because graduates from schools who are not ready to involve the workforce and lack of competence. The skills obtained in educational institutions are not sufficient to be used independently, which occurs in educational institutions only transfer of knowledge alone which results in students not being innovative, creative and not even good at dealing with problems around their environment.

This situation is in accordance with the conditions of teachers at Muhammadiyah Elementary School Medan. Based on the results of interviews with the Chairperson of the Dikdasmen of Medan on October 23, 2017, many Muhammadiyah Elementary School teachers do not shown good performance yet. It can be seen from the teacher absentee level, there are still many teachers who often do not attend the class on time, leaving teaching materials for students to write while he or she goes out to take care of other needs. In addition, there are still some teachers in teaching still using a conventional approach, the teacher does not use methods that make students active. As a result, teachers in teaching are not maximal in carrying out their duties both in class and outside the classroom for example carrying out innovative work and publication work scientific. The impact of low teacher performance influences students' decreased learning achievement.

There are aspects in organizational cultural values at Muhammadiyah Elementary School Medan that are able to meet teacher expectations, so that teachers and organizational members get job satisfaction in their work, these aspects can be highly valued innovations in the organizational culture, appreciation for performance in the form of honorarium, or also the values of the relationship between leaders and subordinates who are not discriminatory. By observing the condition of the Muhammadiyah organization, it is known that the organization is crucial for improving teacher performance.

Robbins and Timothy (2009) there are two factors that influence teachers performance, namely internal and external factors. Internal factors include: education, motivation, job satisfaction, commitment, and work ethic. 
While external factors include: income level, work climate, relationship between coworkers, leadership, and organizational culture. Teacher performance which is an achievement of a person on the work done, can be tangible, seen, counted in number, but in many cases it cannot be calculated and seen, such as ideas to solve a problem, new innovation is an educational quality, it can also be a discovery more efficient work procedures.

In accordance with Indrafachrudi (2000: 53) the factors that influence performance there are two categories, namely: Internal factors and external factors. Internal factors, namely those originating from within a person that can affect one's performance in carrying out their work. They are motivation, interest, talent, character, nature, age, gender, education, and experience. While external factors are factors that come from outside oneself that can affect their performance, including: physical environment, facilities and infrastructure, rewards, atmosphere, policies, administrative systems, and so on. Internal factors are more directed toward the teacher, both individually and institutionally as a professional entity that demands more awareness and responsibility in carrying out roles and functions as a teacher.

Collquit, et al. (2009) state that strong job satisfaction will improve the performance of someone, if a teacher is satisfied in his job it will improve his performance. Job satisfaction of the principal is an important target in human resource management because it will directly or indirectly affect work performance. Collquit (2009) also states that cultural variables, structure, leadership, are variables that affect performance indirectly through job satisfaction. Changes in the education system occur in a relatively fast process that makes many educators or teachers need to adapt relatively quickly so that many educators or teachers need to adapt themselves especially to the effective culture that is being built.

Based on the description above, this research is conducted to find out the influence of organizational culture, honorarium, transformational leadership, and job satisfaction on teacher performance. Teachers who carry out teaching activities assume that their work determines the factors which can improve teacher performance.

\section{LITERATURE REVIEW}

\subsection{Teacher Performance}

Performance leads to an effort in order to achieve better work performance, so that it can be said that performance is a person's success in carrying out a job in accordance with what is set. Mulyasa (2004: 126) defines performance as work performance, work achievement, work results. It reflects performance as an operational or workforce technique, it is shown and achieved. Performance is an action or behavior to achieve work performance. Depdiknas (2004: 4) defines performance with work performance. Surya (2005) describes that performance is the achievement of certain job requirements directly reflected in the achievements.

Based on several explanations regarding the term performance, it can be concluded that performance is an achievement produced by someone in the form of achievement of expectations in accordance with established standards. In this case, the teacher's performance in question is the behavior of a teacher that has an impact on achieving school goals through learning activities in class that can be seen in terms of activities learning planning, implementation and evaluation

\subsection{Job Satisfaction}

In general, humans work to be able to fulfill their needs. They always hope that their desired is in accordance with their expectations so that satisfaction can be achieved within them. Job satisfaction is an individual thing. Each individual has a different level of satisfaction in him.

Robbins and Judge (2006) define job satisfaction as a general attitude of an individual and what they should receive is fulfilled. Hanoko (2001) job satisfaction is a pleasant or unpleasant emotional state in which someone views their work. Hasanbuan (2007: 202) job satisfaction is an emotional attitude that is fun and loves his work. Martoyo (2007: 142) explains job satisfaction is the emotional state of employees of organizations with the level of remuneration that is indeed desired by the employees concerned.

Based on the explanations above, it can be concluded that job satisfaction is a person's feelings for their work, which can be seen from a positive attitude towards their work and everything faced in the work environment. In this case, teacher job satisfaction is the feeling of the teacher about his work in school which can be seen from a positive attitude towards his work, through indicators: challenging work, (b) a fair reward system, (c) conditions that are supportive, and (d) the nature of coworkers.

\subsection{Transformational Leadership}

An organization can run well and smoothly if it has a good leader. Transformational leaders evaluate the ability and potential of each subordinate to carry out the job, while considering the possibility to expand the responsibilities and authority of subordinates in the future.

According to Robbins and Timonthy (2009: 471) transformational leaders devote attention to the things and developmental needs of each follower, transformational leaders change followers' awareness of problems by 
helping them view old problems in new ways, and they are able to excite, arouse, and inspire followers to spend extra efforts to achieve the group's goals. Bush (2009) states transformational leadership is the ability to provide and motivate followers to achieve results that are greater than those originally planned and for internal rewards. Yulk (2009: 290) transformational leadership calls for moral values of followers in its efforts to increase their awareness of ethical issues and to mobilize their energy and resources to reform institutions.

Based on the explanations above, it can be concluded that transformational leadership is the ability to influence and direct subordinate behavior to achieve organizational goals. In this case, the principal's transformational leadership is the ability of the principal to influence and direct the teacher to achieve school goals, which can be seen through indicators: having charisma, inspiring subordinates, stimulating subordinate intellectuals, and showing attention to individuals.

\subsection{Reward}

Rewards are positive motivators for employees to improve performance. Giving rewards is useful for organizations and employees because rewards are used to encourage employees to improve the quality and quantity of work. Therefore, income or compensation is the right of every employee, it becomes a very important factor for individuals, as the psychologist states that individuals have many needs, but only some can be directly satisfied with money, while other needs can be satisfied indirectly with money.

According to Sulitiyani and Rosidah (2003: 206) rewards are a broader context regarding the provision of compensation by an organized institution that covers all the benefits packages provided by the organization to its members and mechanisms and procedures where profits can be distributed. Rizky (2001:9) rewards have a broader scope of wages or salaries. Rewards cover all expenses incurred by the organization for workers, both directly and indirectly. Sukarto (2006: 1) argues that compensation is the preparation, implementation, maintenance, communication, and evaluation. Rewards are everything that an organization gives to its employees both financially and non-financially in exchange for how much it contributes to the organization in achieving the performance standards set by the organization

Based on some of the explanations above, it can be concluded that reward is all forms of compensation given by the organization to employees financially and non-financially as remuneration for the implementation of duties or employee contributions to the organization. In this case, the compensation received by the teacher is a form of compensation given by the school to the teacher both financially and non-financially for its contribution to the achievement of school goals, which can be seen from: salaries, overtime wages, incentives, work facilities, as well as security and safety work.

\subsection{Organizational Culture}

The achievement of organizational goals or the success of an organization in improving performance and productivity must be supported by the existence of an organizational culture. It is in accordance with the vision and mission specified. According to Robbins (2006) organizational culture is a system of meanings shared by members who distinguish the organization from other organizations. Organizational culture (culture developed in an organization) needs to be created and accustomed through learning, directed towards achieving organizational goals.

Davis and Jhon (2000) organizational culture is a norm that consists of beliefs, attitudes, core values, and behavioral patterns carried out by people in the organization, and all of these affect organizational performance. In line with Wibowo's opinion (2010: 371), organizational culture is all assumptions and perceptions about something that is right and legitimate. Core values are dominant values that are accepted throughout the organization, whereas behavior patterns are the way people act against others.

Based on some of the explanations above, it can be concluded that organizational culture is a set of guidelines adopted by members of the organization containing values, norms, habits, and behavioral patterns that apply in the organization. In this case, organizational culture is a guideline adopted by the teacher as a member of a school organization containing values, norms, habits, and behavioral patterns that can be assessed from indicators: innovation and risk taking, attention to detail, outcome orientation, people orientation, team orientation, aggressiveness, and stability.

\section{RESEARCH METHODS}

This research is conducted in Muhammadiyah Elementary School Medan. The selection of research sites is because researchers have coordinated with Muhammadiyah Primary Education School principals in Medan, related to the decline the performance of elementary school teachers. The research population is teachers who teach at the Muhammadiyah Elementary School Medan. In complete terms, the total population of the study can be seen in the Muhammadiyah Primary and Secondary Education Office in Medan totaling 570 teachers, while the sample of 235 respondents is then determined by the number of samples in each school. 


\subsection{Data analysis technique}

Analysis of the data used in this study includes descriptive analysis, analysis requirements test, and hypothesis testing. In accordance with the research hypothesis and research objectives, hypothesis testing is carried out using path analysis.

\subsection{Test of Research Hypothesis}

To test the hypothesis, path analysis is used with the computer program SPSS for Windows version 24.0. In testing the hypothesis, a significance level of $\alpha$ is used for 0.05 . In connection with the use of path analysis, AlRasjid suggests that when conducting an analysis, it must be firstly described in a diagrammatic structure of causal relationships with causal variables and consequent variables. Based on theoretical models developed in research this is as the model used the research variable path diagram.

\subsection{Discussion of Research Results}

The description of the data presented in this section includes variable data on Organizational Culture (X1), Rewards (X2), Transformational Leadership (X3), Job Satisfaction (X4), and Teacher Performance (X5). The data is the result of quantifying respondents' answers to the questionnaire distributed to teachers at Muhammadiyah Elementary School Medan. The number of questionnaires distributed is 235 sets according to the number of samples.

Model Sub Structure I is the direct influence of organizational culture, reward and transformational leadership variables on the job satisfaction of Muhammadiyah Elementary School teachers in Medan. The diagram of model Substructure I is presented in Figure I

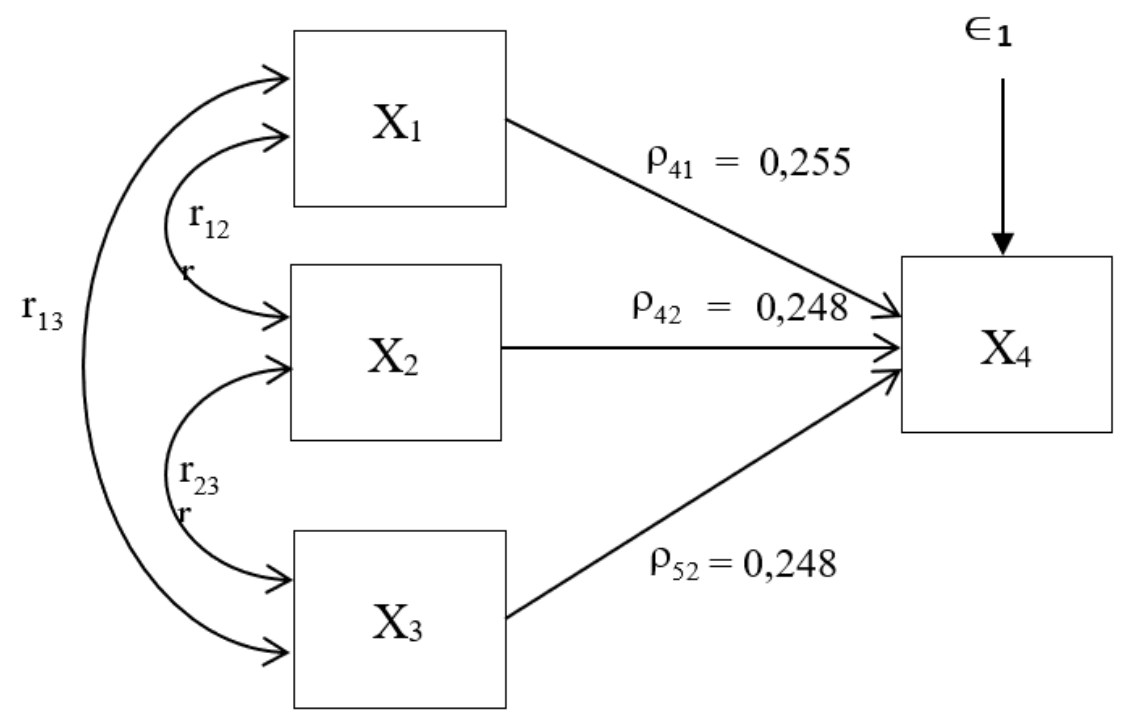

Figure I. Model Sub Structure I

Explanation:

$\mathrm{X}_{1}=$ Organizational Culture

$\mathrm{X}_{2}=$ Rewards

$\mathrm{X}_{3}=$ Transformational Leadership

$\mathrm{X}_{4}=$ Job Satisfaction

$\epsilon_{1}=$ Other Influences

Based on the cost of the correlation coefficients, the path coefficients are calculated, the cost of the path coefficients from Sub Structures I is presented in Table 1. 
Table 1. Summary of Path Coefficient Results of Model Sub Structure I Coefficients

\begin{tabular}{|l|l|l|l|l|l|}
\hline \multirow{2}{*}{ Model } & \multicolumn{2}{|l|}{$\begin{array}{l}\text { Unstandardized } \\
\text { Coefficients }\end{array}$} & Standardized Coefficients & & \\
\cline { 2 - 5 } & B & Std. Error & Beta & T & Sig. \\
\hline 1(Constant) & $35,070,240$ & & $3,796,000$ \\
Organizational Culture &, 270 &, 062 &, 255 & 4,363 &, 000 \\
Reward &, 240 &, 057 &, 248 & 4,242 & 000 \\
Transformational Leadership &, 271 &, 064 &, 248 & $4,252,000$ \\
\hline
\end{tabular}

a. Dependent Variable: Job Satisfaction

Table 1 above shows the value of path coefficients between variables in the Model Sub Structure I . The path coefficient of the organizational culture variable (X1) to the variable job satisfaction (X4) reaches 0.255. Means there are $25.5 \%$ direct effects of organizational culture variables on job satisfaction of Muhammadiyah Elementary School teachers in Medan. The variable reward path coefficient (X2) for the variable job satisfaction (X4) reaches 0.248 . This means that there are $24.8 \%$ direct effects of variable rewards on job satisfaction of Muhammadiyah Elementary School teachers in Medan. The path coefficient of transformational leadership variable $(\mathrm{X} 3)$ on the variable job satisfaction (X4) reaches 0.248 . Means there are $24.8 \%$ direct effects of transformational leadership variables on job satisfaction of Muhammadiyah Elementary School teachers in Medan.

Model Sub Structure II is the direct influence of organizational culture, reward, transformational leadership, and job satisfaction variables on the performance of Muhammadiyah Elementary School teachers, as follows.

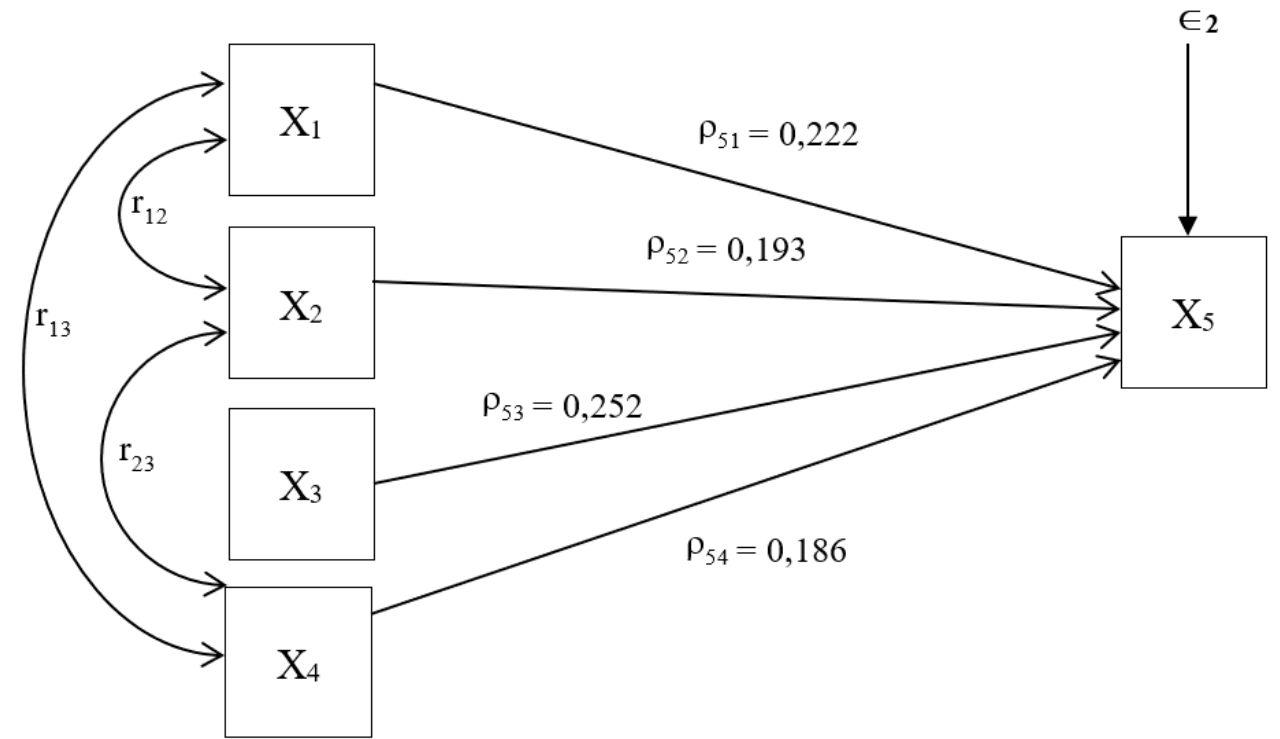

Figure 2. Model Sub Structure II

Explanation:

$\mathrm{X}_{1}=$ Organizational Culture

$\mathrm{X}_{2}=$ Rewards

$\mathrm{X}_{3}=$ Transformational Leadership

$\mathrm{X}_{4}=$ Job Satisfaction

$\mathrm{X}_{5}=$ Teacher Performance

Based on the cost of the correlation coefficients, the path coefficients are calculated, the cost of the path coefficients from Sub Structures I is presented in Table 2 below. 
Table 2. Summary of Path Coefficient Results Model Sub Structure II

Coefficients $^{\mathrm{a}}$

\begin{tabular}{|c|c|c|c|c|c|c|}
\hline \multirow{2}{*}{\multicolumn{2}{|c|}{ Model }} & \multicolumn{2}{|c|}{$\begin{array}{l}\text { Unstandardized } \\
\text { Coefficients }\end{array}$} & \multirow{2}{*}{\begin{tabular}{|l} 
Standardized \\
Coefficients
\end{tabular}} & \multirow[b]{2}{*}{$\mathrm{t}$} & \multirow[b]{2}{*}{ Sig. } \\
\hline & & $\mathrm{B}$ & Std. Error & & & \\
\hline \multirow[t]{5}{*}{1} & (Constant) & 9,659 & 6,068 & & 1,592 & 113 \\
\hline & $\begin{array}{l}\text { Organizational } \\
\text { Culture }\end{array}$ &, 157 &, 041 & 222 & 3,823 &, 000 \\
\hline & Rewards &, 125 & 037 &, 193 & 3,330 &, 001 \\
\hline & $\begin{array}{l}\text { Transformational } \\
\text { Leadership }\end{array}$ &, 136 &, 042 &, 186 & 3,222 &, 001 \\
\hline & Job Satisfaction & 168 &, 042 &, 252 & 4,015 &, 000 \\
\hline
\end{tabular}

a. Dependent Variable: Teacher Performance

Table 2 above shows the value of the correlation coefficient between variables in Model Sub Structure II. The path variable of the Organizational Culture $\left(\mathrm{X}_{1}\right)$ coefficient on the performance variable of Muhammadiyah Elementary School teachers $\left(\mathrm{X}_{5}\right)$ reaches 0.222 . It means that there are $22.2 \%$ direct effects of organizational culture variable $\left(\mathrm{X}_{1}\right)$ on the performance of Muhammadiyah Elementary School teachers $\left(\mathrm{X}_{5}\right)$. The variable reward path coefficient $\left(\mathrm{X}_{2}\right)$ for the variable performance of the Muhammadiyah Elementary School teacher $\left(\mathrm{X}_{5}\right)$ reaches 0.193 . This means that there are $19.3 \%$ of the direct effects of variable rewards $\left(\mathrm{X}_{2}\right)$ on the performance of Muhammadiyah Elementary School teachers $\left(\mathrm{X}_{5}\right)$. The path coefficient of transformational leadership variable $\left(\mathrm{X}_{3}\right)$ towards the performance variable of Muhammadiyah Elementary School teacher $\left(\mathrm{X}_{5}\right)$ reaches 0.186 . It means that there are $18.6 \%$ direct effects of transformational leadership variable $\left(\mathrm{X}_{3}\right)$ on the performance of Muhammadiyah Elementary School teachers $\left(\mathrm{X}_{5}\right)$. The job satisfaction variable $\left(\mathrm{X}_{4}\right)$ path coefficient on the Muhammadiyah elementary school teacher performance variable $\left(\mathrm{X}_{5}\right)$ reaches 0.252 . It Means there are $25.2 \%$ direct effect of job satisfaction variable $\left(\mathrm{X}_{4}\right)$ on the performance of Muhammadiyah Elementary School teachers $\left(\mathrm{X}_{5}\right)$.

\subsection{Direct and Indirect Effects}

Based on the cost of correlation coefficients and path coefficients obtained from the results of calculations, the next direct and indirect effects of exogenous variables are calculated on endogenous variables, total and non-lane influences in Table 3 below.

Table 3. Summary of Calculation of Path Coefficients, Direct and Indirect Effects, Total and Non-Path

\begin{tabular}{|l|l|l|l|}
\hline \multirow{3}{*}{ Model } & $\begin{array}{l}\text { Exogenous Variable } \\
\text { towards Endogenous } \\
\text { Variable }\end{array}$ & Effects & Relative \\
\cline { 3 - 4 } & & & \\
\hline \multirow{5}{*}{ I } & X1 towards X4 & $4,0 \%$ & $25,5 \%$ \\
& X2 towards X4 & $5,3 \%$ & $24,8 \%$ \\
& X3 towards X4 & $7,8 \%$ & $24,8 \%$ \\
\hline \multirow{5}{*}{} & X1 towards X5 & $6,4 \%$ & $22,2 \%$ \\
& X2 towards X5 & $2,4 \%$ & $19,3 \%$ \\
& X3 towards X5 & $1,5 \%$ & $18,6 \%$ \\
& X4 towards X5 & $6,3 \%$ & $25,2 \%$ \\
\hline
\end{tabular}

The proportional effect of organizational culture on job satisfaction of Muhammadiyah culture influences the job satisfaction of Muhammadiyah Elementary School teachers in Medan by $25.2 \%$. Thus, to increase job satisfaction of Muhammadiyah Elementary School teachers in Medan, it can be done by increasing the culture of Muhammadiyah Elementary School organization in Medan. In other words, organizational culture can play a role in efforts to increase job satisfaction of Muhammadiyah Elementary School teachers in Medan.

The effect of proportional rewards on job satisfaction of Muhammadiyah Elementary School teachers in Medan is $5.3 \%$. Rewards relatively affect the job satisfaction of Muhammadiyah Elementary School teachers by 24.8\%. Thus, to increase job satisfaction of Muhammadiyah Elementary School teachers, it can be done by increasing the rewards. In other words, rewards can play a role in efforts to increase job satisfaction of Muhammadiyah Elementary School teachers in Medan.

The proportional influence of transformational leadership on job satisfaction of Muhammadiyah Elementary School teachers is $7.8 \%$. Transformational leadership relatively influences the job satisfaction of 
Muhammadiyah Elementary School teachers by $24.8 \%$. Thus, to improve job satisfaction of Muhammadiyah Elementary School teachers, it can be done by improving transformational leadership. In other words, transformational leadership can play a role in efforts to increase job satisfaction of Muhammadiyah Elementary School teachers in Medan.

The proportional influence of organizational culture on the performance of Muhammadiyah Elementary School teachers is $6.4 \%$. Organizational culture relatively affects the performance of Muhammadiyah Elementary School teachers by $22.2 \%$. Thus, to improve the performance of Muhammadiyah Elementary School teachers, it can be done by increasing the culture of Muhammadiyah Elementary School organization. In other words, organizational culture can play a role in efforts to improve the performance of Muhammadiyah Elementary School teachers in Medan.

The proportional effect of rewards on the performance of Muhammadiyah Elementary School teachers is $2.4 \%$. Organizational culture relatively affects the performance of Muhammadiyah Elementary School teachers by $19.3 \%$. Thus, to improve the performance of Muhammadiyah Elementary School teachers, it can be done by increasing the rewards of Muhammadiyah Elementary Schools teachers. In other words, rewards can play a role in efforts to increase job satisfaction of Muhammadiyah Elementary School teachers in Medan.

The proportional influence of transformational leadership on the performance of Muhammadiyah Elementary School teachers is $1.5 \%$. Transformational leadership relatively affects the performance of Muhammadiyah Elementary School teachers by $18.6 \%$. Thus, to improve the performance of Muhammadiyah Elementary School teachers, it can be done by improving transformational leadership. In other words, transformational leadership can play a role in efforts to improve the performance of Muhammadiyah Elementary School teachers in Medan.

The proportional effect of job satisfaction on the performance of Muhammadiyah Elementary School teachers is $6.3 \%$. Job satisfaction relatively affects the performance of Muhammadiyah Elementary School teachers by $25.2 \%$. Thus, to improve the performance of Muhammadiyah Elementary School teachers, it can be done by increasing job satisfaction of Muhammadiyah Elementary School teachers. In other words, job satisfaction can play a role in efforts to improve the performance of Muhammadiyah Elementary School teachers in Medan.

The direct effect of organizational culture on job satisfaction is 0.255 . The direct effect of job satisfaction on the performance of Muhammadiyah Elementary School teachers is 0.252 . Thus, the indirect influence of organizational culture on the performance of Muhammadiyah elementary school teachers through job satisfaction variables is 0.065 . The results of these findings indicate an increase in the organizational culture of Muhammadiyah Elementary School is instrumental in efforts to improve the performance of Muhammadiyah Elementary School teachers, but it must pay attention to job satisfaction.

The direct effect of rewards on job satisfaction is 0.248 . The direct effect of job satisfaction on the performance of Muhammadiyah Elementary School teachers is 0.252 . Thus, the indirect effect of rewards for the performance of Muhammadiyah Elementary School teachers is through job satisfaction variables of 0.083 . The results indicate that there are indirect variable rewards for the performance of Muhammadiyah Elementary School teachers. The results of these findings indicate an increase in rewards plays a role in efforts to improve the performance of Muhammadiyah Elementary School teachers, but it must pay attention to job satisfaction.

The direct effect of transformational leadership on job satisfaction is 0.248 . The direct effect of job satisfaction on the performance of Muhammadiyah Elementary School teachers is 0.252 . Thus, the indirect influence of transformational leadership on the performance of Muhammadiyah Elementary School teachers through job satisfaction variables is 0.067 . The results of these findings indicate that the improvement of transformational leadership has a significant role in efforts to improve the performance of Muhammadiyah Elementary School teachers, but it must pay attention to job satisfaction.

\section{DISCUSSIONS}

This study aims to determine the effect of exogenous variables on the variable performance of Muhammadiyah elementary school teachers in Medan. The performance of the Muhammadiyah Elementary School teacher is the behavior that is directly involved in carrying out the tasks, activities, and responsibilities. The performance of the Muhammadiyah Elementary School teacher refers to the behavior of the Muhammadiyah Elementary School teacher who is positive or negative in achieving the objectives of Muhammadiyah Elementary School. The performance of Muhammadiyah Elementary School teachers is seen from three dimensions, namely: learning planning, learning implementation, and learning evaluation.

From the results of the study, researchers find a new model of research paradigm that is produced as a result of the analysis of research data described as follows. 


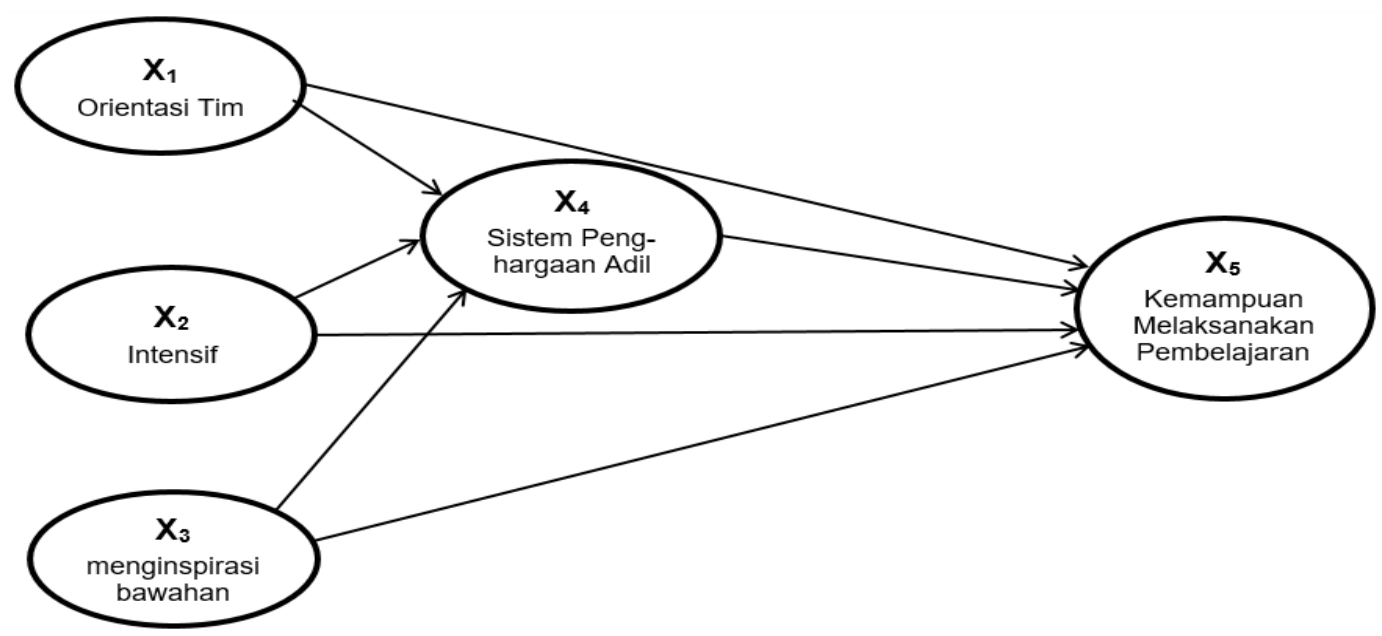

Figure 3. New Model of Research Paradigm

Based on Figure 3 above, improving teacher performance, it can be done by optimizing the ability of school principals to inspire teachers in schools. The principal's transformational ability is to inspire teachers to conduct learning activities well in class according to the procedures and actions chosen. Good organizing will provide benefits in the form of: (1) good relations among school staff, so that it will facilitate the achievement of school goals; and (2) every school staff, especially teachers, can clearly understand their duties, obligations and responsibilities.

Figure 3 also shows an increase in elementary school teachers in carrying out learning can be done through optimizing the dimensions of team orientation on organizational culture variables. The results of this study support the research conducted by Sharma (2017) concludes the relationship of organizational culture to job satisfaction. The results of the study show that organizational culture is positive and significantly related to job satisfaction and organizational commitment. Gull's research and Fariha (2012) find that organizational culture and job satisfaction are very important factors for schools.

In addition to that, Figure 3 shows an increase in elementary school teachers in carrying out learning can be done through optimizing the dimensions of incentives that are right on the reward variable. With the right incentives, a teacher can carry out the process of evaluating and carrying out the duties of a person or group of people or work units within the school in accordance with the performance standards or objectives set. The results of this study support the research conducted by Ihedinmah, et al. (2015) stating that organizations currently operate in highly dynamic and highly competitive environments. In order to remain relevant in the market, they must be able to respond quickly to changing customer demands. Salah (2016) shows how employees improve performance in the reward system. There is a positive relationship between rewards (extrinsic and intrinsic) and employee job performance.

Figure 3 also shows an increase in elementary school teachers in implementing learning can be done through optimizing dimensions to inspire subordinates to transformational leadership variables. The principal can view the work as a self-realization, service and vocation, then she or he will like the job, so she or he always tries to devote his energy, thoughts and feelings to completing the work responsibly so that quality work is achieved. The results of this study support the research conducted by Elgelal and Noermijati (2014). They conclude the effect of transformational leadership directly on employees' motivation, job satisfaction, and employee performance.

Figure 3 also shows an increase in elementary school teachers in carrying out learning can be done through optimizing the fair dimension of a fair reward system on job satisfaction variables. School leaders in organizing subordinates must also be able to act fairly on themselves in a fair reward system. The results of this study are supported by Akafo and Peter (2015.) they assess the relationship between reward and job satisfaction, to identify perceptions of academic staff and administrators about gifts and recognition and to explain the challenges of implementing gifts at private tertiary institutions.

The factors examined for the influence on the performance of teachers at the Medan Muhammadiyah Elementary School include: organizational culture, rewards, transformational leadership, and job satisfaction.

\section{CONCLUSION}

Based on the previous descriptions and the results of data analysis and discussion of the results of the research conducted, the adaptive Teacher Performance model implemented at Muhammadiyah Elementary School is built on associative causal relationships between exogenous variables of organizational culture, rewards, transformational leadership, and job satisfaction with endogenous variable teacher performance. Teacher's 
performance model findings of this study explain that improving teacher performance can be done in two ways, namely: through strengthening organizational culture, rewards, transformational leadership, and job satisfaction which will directly lead to better teacher performance. In addition, it can also be done through strengthening organizational culture, rewards, and transformational leadership which will directly lead to increased job satisfaction which further improves teacher performance.

\section{REFERENCES}

Akafo, Vera and Peter Agyekum Boateng. 2015. "Impact of Reward and Recognition on Job Satisfaction and Motivation". European Journal of Business and Management, Vol.7, No.24, 2015.

Bush, Toni. 2009. Educational Leadership and Management. London: Sage Publication Ltd. Collquitt, Jason A., LePine, Jeffery A. and Wesson, Michael J. 2009., Organization Behavior. New York: McGraw Hill.

Davis, Keith, and Jhon W. Newstrom, 2000. Behavior in Organizations, Seventh Edition, Agus Darma Language Transfer, Jakarta: Erlangga.

Ministry of National Education.2004, Performance Improvement of Principals, Jakarta Directorate General of Primary and Secondary Education, Directorate of High School Education.

Elgelal, Kamel Saleh Khalifa and Noermijati. 2014. "The Influences of Transformational Leaderships on Employees Performance (A Study of Economics and Business Faculty Employee at University of Muhammadiyah Malang)". Asia-Pacific Management and Business Application, 3 (1) 48 - 66, (C) UB 2014.

Gull, Shamaila and Fariha Azam. 2012. "Impact of Organizational Culture Type on Job Satisfaction Level of Employees' in Different Organizations of Lahore, Pakistan". International Journal of Academic Research in Business and Social Sciences, December 2012, Vol. 2, No. 12.

Gibson, Ivancevich., Donnelly and Konopaske. 2011. Behavior Oganizations, Structure, Processes, .Fourteenth edition. New York: McGraw-Hill.

Handoko, T. Hani. 2001. Personnel Management and Human Resources, Second Edition. Yogyakarta: BPFE.

Hasibuan, Malayu S.P. 2007. Human Resource Management. Jakarta: Bumi Aksara.

Ihedinmah, Nnaji., Nnadozie Chijioke. Egbunike, and Francis Chinedu. 2015. "Effect of Rewards on Employee Performance in Organizations: A Study of Selected Commercial Banks in Awka Metropolis". European Journal of Business and Management, Vol.7, No.4, 2015.

Indrafachrudi.2000. Methods of Job Assessment and Affecting Factors. Contents: Ghalia Indah.

Martoyo, Susilo. 2007. Human Resource Management. Yogyakarta: BPFE.

Mulyasa, E. 2004. Competency Based Curriculum. Bandung: Teenager Rosdakarya.

Robbins, S. P and Timonthy A. Judge. 2009 Organizational Behavior New York: Upper Sadle River.

Robbins, S. P and Timonthy A. Judge. 2006. Organizational Behavior, Volume 2. Jakarta: Index.

Rizky, Achmad S. 2001. Management of Company Employee Replacement and Wages, First Print. Jakarta: Main Gramedia.

Sahulata, O. 2009 Improves the Quality of Performance of Educators. Education Article.

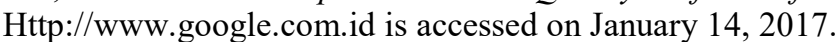

Mohammed Raja Abulraheem. 2016. "The Influence of Rewards on Employees Performance".

British Journal of Economics, Management \& Trade, 13 (4): 1-25, 2016.

Sharma, Pooja. 2017. "Organizational Culture As A Predictor of Job Satisfaction: The Role of Age and Gender". Management, Vol. 22, 2017, 1, pp. 35-48.

Sulistiyani, A.T and Rosidah. 2003. Human Resource Management. Yogyakarta: Graha Ilmu.

Sunarto. 2006. Introduction to Marketing Management. Yogyakarta: Ust Press. Surya Dharma. 2005. Performance Management: The Philosophy of Theory and Its Application. Yogyakarta: Learning Library.

Wibowo, 2010, Performance Management. Jakarta: Rajawali Press.

Yukl, Gary. 2009. Leadership in Organizations Edition 5. (Language Expert Budi Suprianto). Jakarta: Index. 